\title{
Unmastering the Script: Education, Critical Race Theory, and the Struggle to Reconcile the Haitian Other in Dominican identity, by Sheridan Wigginton and Richard T. Middleton IV
}

\author{
Alexandra Channell • Texas Christian University
}

\begin{abstract}
Unmastering the Script: Education, Critical Race Theory, and the Struggle to Reconcile the Haitian Other in Dominican Identity. Wigginton, Sheridan and Richard T. Middleton IV. The University of Alabama Press, 2019
\end{abstract}

$\mathrm{I}$ n Unmastering the Script: Education, Critical Race Theory, and the Struggle to Reconcile the Haitian Other in Dominican Identity, Sheridan Wigginton and Richard T. Middleton IV investigate the relationship between the positionality of Haitians in Dominican society and the social construction of Dominican identity in the Dominican Republic. Wigginton and Middleton examine Dominican curricular materials to illustrate dominant ideology in the Dominican Republic's demarcation of Haitian descent, identity and blackness as distinct from and inferior to Dominican descent, identity and blackness. The authors refer to this discriminatory narrative as the Haitian Other master script. Throughout the book, the authors interrogate the influence of this Haitian Other master script in shaping Dominican history and defining Dominican national identity.

Wigginton and Middleton begin the book with an introduction describing the turbulent history between Haiti and the Dominican Republic. This section outlines the complex interplay of racial identity, politics, and curriculum in Dominican society, justifying the use of critical race theory as the framework for the text. The authors organize the remainder of the book into five chapters that offer varying vantage points for examining white supremacy and black inferiority embedded within social science textbooks and historical biographies taught to school-age students.

In Chapter One, "La Trinitaria: The Elevation of Whiteness and Normalization of a Pigmentocracy in Dominican Society", Wigginton and Middleton analyze the biographies of three revered national "heroes" commonly included in school curriculum: Juan Pablo Duarte, Ramón Matías Mella, and Francisco del Rosario Sánchez. The authors highlight how these biographies position phenotypic traits of whiteness at the crux of elevated social status and patriotism. Descriptions of these political figures extend beyond their personal achievements and contributions to also emphasize ancestry. The narratives support pigmentocracy by suggesting that skin hues closer to whiteness are superior, and by "clarifying" that darker skin hues of Dominicans do not reflect Haitian ancestry. The authors effectively embed a portrait of each member of La Trinitaria within the text to provide the reader with additional context and illustrate the distancing of Haitian blackness from Dominican blackness.

In Chapter Two, "Truth and Trujillo: A Critical Approach to Studying the Trujillo Dictatorship", Wigginton and Middleton describe the leadership of Rafael Leónidas Trujillo Molina, who served as a dictator in the Dominican Republic for thirty years. During his reign, he propagated a malicious anti-black and anti-Haitian agenda. Through analysis of an eighth-grade social science textbook, Wigginton and Middleton identify lessons and activities related to Trujillo's regime and explicate missed opportunities for students to engage in critical civic discourse that interrogates the Haitian Other master script, challenges the political and social agendas of former leaders, and evaluates the subsequent impact on Dominican society. These missed opportunities not only reflect poor pedagogy but also reinforce detrimental messages for all students, especially students of Haitian descent.

Chapter Three, "The "Masters" of the Script: Joaquín Balaguer, José Francisco Peña Gómez, and the Anti-Haitian Nation", examines biographies of politicians published in 2006 and explores how the "otherness" of Haitians often promotes political agendas. They describe the political strategy of racial priming commonly used in the United States, and demonstrate how similar tactics are exercised in the Dominican Republic. The biography of politician José Francisco Peña Gómez exemplifies how textbooks often 
portray Haitians as a threat to Dominicans, with Dominican identity or dominicanidad (Dominican-ness) as something to be proven and accepted, and Haitian identity as a hurdle to overcome.

Chapter Four, "Dominican National Identity: Social Science Textbooks and the Boundaries of Blackness", compares the characterization of national identity in textbooks published a decade apart. The authors evaluate three themes commonly perpetuated in the Dominican Republic as a rubric for their analysis:

(1) blackness represents less desirable social status

(2) blackness can be prevented through generational blanqueamiento (whitening)

(3) blackness is represented by negative and exaggerated stereotypes

Illustrations in the older textbooks depicted darker-skinned people in lower wage jobs and with exaggerated and stereotypical physical features. While the authors noted that the more recent textbook illustrations portrayed fewer negative depictions of darker-skinned people, they also suggested that the underlying messaging of identifying and constructing Dominican identity based on European traits remained largely unchanged.

In Chapter Five, "Color, Classrooms, and the Haitian Other", Wigginton and Middleton describe the failure of the Plan decenal de educación acción (Ten-Year Education Plan in Action), a project intended to improve content in social science textbooks. Despite the plan's stated goals of focusing on the construction of a national identity that opposes racism and othering, textbook content following the plan's institution continued to perpetuate mindsets and processes aligned with Eurocentricity and the erasure and rejection of African ancestry. The authors suggest that progress in dismantling the Haitian Other master script and prejudicial views of dominicanidad relies on adopting culturally relevant textbooks, and instituting culturally relevant pedagogy to engage students in historically accurate, age-appropriate, critical discussions that intellectually challenge negative perceptions of blackness. Wigginton and Middleton close the text by acknowledging that culturally relevant textbooks serve as only one tactic in reconstructing the Haitian Other master script. The authors recommend repurposing the Haitian Other master script to provide a more inclusive narrative of Dominican history and illustrate more holistic representations of Dominican identities, rather than only portraying stories that favor whiteness.
In Unmastering the Script: Education, Critical Race Theory, and the Struggle to Reconcile the Haitian Other in Dominican Identity, Wigginton and Middleton constructively contribute to the dialogue regarding racial identity and politics in the Dominican Republic through the lens of Dominican curricula. They provide an informative synopsis of the "othered" identity of Haitians in the Dominican Republic, which is central to readers' understanding of the text. The authors engage readers with numerous graphics, contextual examples, and Spanish passages, which contribute to the authenticity of the provided information, leaving readers more informed about the role of the Haitian Other master script in Dominican society.

While the authors broach connections between textbook adoptions, political motivations, and critical race theory, an explicit definition and less nuanced application of the term "critical race theory" could benefit readers and strengthen the rationale for this critical framework. Further, given that race is the focal point of this text, a researcher positionality statement could provide additional insight to the reader. Another helpful inclusion could be more information surrounding the selection criteria (rationales for inclusions and exclusions) of the social science textbooks selected for this book, and the methods used in this research. This inclusion might also assist readers in constructing greater comprehension of the pervasiveness of the Haitian Other master script throughout Dominican curricula and society.

Even so, Wigginton and Middleton not only offer critical information about textbook adoptions in the Dominican Republic, but also offer valuable insight into the benefits of culturally responsive (and inclusive) pedagogy, and the implications of vetting textbooks through culturally responsive lenses prior to use in the classroom. Their vivid examples reveal the impact of classroom materials on students' identities, which may be informational to educators seeking to support the identity development of students who are often underrepresented or negatively represented in curriculum. The authors weave a thread of hope and admonition relevant to educators and policymakers striving for racial equity: reform is vital and overdue.

Alexandra Channell, Texas Christian University 